\title{
The harmonious relationship between human beings and nature in traditional song lyric during sintren ritual
}

\author{
Siti Ayu Masthuroh ${ }^{*}$, Prihantoro \\ Department of Linguistics, Faculty of Humanities, Diponegoro University, Semarang - Indonesia
}

\begin{abstract}
This study aims to describe how communication patterns and symbolic meaning in the procession of Cirebon sintren ritual. The data that researchers use are limited to traditional songs accompanying sintren procession so that the research discussion can be explained in a focused and directed manner. This research is a descriptive qualitative research using the ethnographic theory of communication. Research data analyzed using domain analysis techniques based on unit theory analysis presented by Dell Hymes about the setting (communication situation), event (communication event), and act (communication act). The results showed that the choice of the floral lexicon ginger, galangal, and zingiber in traditional song lyric during sintren ritual reflects the characteristics of Cirebon society who live in areas with geographical conditions of lowlands and highlands. These three floral lexicons are everyday plants that they encounter; meaning language use in a society cannot be separated from its natural environment. Meanwhile the symbolic meaning in the fragment of the song and the gesture of the sintren procession reflect the state of society during the colonial period.
\end{abstract}

Keywords: Traditional song; sintren ritual; natural environment

\section{Introduction}

Indonesia is an archipelago consisting of various ethnic groups. According to BPS census data in 2010 there were 1,340 ethnic groups in Indonesia. The diversity of ethnic groups in Indonesia does not only affect the number of language in each regions but also the diversity of cultures and traditions also possessed by Indonesia, due to the essence of language and culture cannot be separated from each other. Culture includes a set of patterns and ways of life of people and the community uses language as the main intermediary tool for forwarding, applying and communicating their culture. The use of language in culture we can see in the ritual communication.

Sintren is one of the rituals of Cirebon society. This tradition experiences development and distribution in Central Java. In addition, people in West Java even recognize this tradition and be attached to their lives, including in the area of Cirebon and Indramayu. Sintren is a

Corresponding author: ayumasthuroh@gmail.com 
magical art of the community in north coast Java [1]. At the beginning of its appearance, sintren is used in life fishing community.

Sintren is done by mothers and daughters to wait for her husband came home from fishing to catch fish. Sintren comes from 2 words. "si" is the person who means her, and "tren" (tri) which means princess. That is, sintren is a calling of a princess spirit to then be inserted into the body of a girl (sintren dancer). So deep this ritual, the body of the girl who becomes a sintren dancer is unconscious and moved by the spirit. Sintren rituals are full of symbolic interactions. Symbolic interaction shows that humans interact with each other at the same time share understanding of certain terms and actions and understand events through certain ways as well [6]. Meanwhile Ahmadi declare that George Herbert Mead who is the inventor of symbolic interaction theory states that symbolic interaction is everything that is interconnected with the formation of meaning of a objects or symbols, both inanimate and living objects, through a process communication as verbal messages and non-verbal behavior and the ultimate goal interpret symbols or symbols (objects) based on mutual agreement that applies in certain regions or community groups [2].

The focus of this research is on the Cirebon Sintren ritual communication, while the goal the research is to describe how the communication patterns of the ritual of Cirebon Sintren and reveal what the symbolic meaning in the procession of the Sintren ritual as reflection and cultural form of coastal communities. The data that researchers use is limited to ballad accompaniment of the sintren procession so that the discussion of the research can be presented in a manner focused and directed. What is meant by ritual communication is the process of meaning message to the belief system and religious activities adopted by a group. Through the ritual procession, the meaning of certain symbols occurs the occurrence of the ritual communication process [10]. Meanwhile according to Hamad [3] ritual communication is a relationship that has closely related to the activities of sharing, participating, gathering, friends from one another a community that has one common belief. The existence of ritual activities is part from customs in culture. Ritual is a technique or a way of making a habit of being holy. Rituals maintain and create myths, social customs and religion. Ritual form can be dance, drama and prayer and can be personal or group. At first the ritual is social and then economical then developed into the sacred ordinances of religion.

This research uses ethnography of communication theory. Ethnography of communication is a study of communication patterns, cultural descriptions and analysis as well as linguistic codes. Ethnography of communication is a study of the role of language in a communication behavior of society [5]. In ethnographic communication study the research data used are ritual languages or sacred languages used on certain occasions and events.

There are several previous studies that have a correlation with this study. Rifa'i [10] examines the Ethnographic Communication of Tingkeban Neloni and Mitoni Rituals and explained that the implementation of the seven rituals can be carried out at parents's house or at grandparents's house, as well witnessed by relatives, neighbors and people of the village of Sumbersuko. The communicative events ritual can be seen through the topic, function and purpose, settings, participants, forms messages, message content, sequence of actions, rules of interaction and norms. While communicative activities as it understands and knows the seven-month ritual procession is the master of ceremonies seven months (tingkeban). Meanwhile, Maryanti [8] in his research entitled Ethnography Communication in the Thugun Mandi Tradition explained about the analysis of the Thugun Mandi tradition through the perspective of communication ethnography based on the unit of analysis. In addition, Handayani [4] conducted a similar study by the title Communication Pattern of the Rice Planting Season Slametan Ritual in Ngemplak, Sambikerep, from the research Handayani found that slametan ritual communication during the rice planting season is done in three series, namely "keleman", "metek", and "munggo lombung" which have a different significant symbol that automatically recognize the ritual that is being performed. Furthermore, Manafe 
[7] examines Ritual Communication on Atoni Pah Meto's Farming Culture in East Nusa Tenggara and discuss the series of agricultural ritual processions run by the Atoin people Pah Meto and traditional forms of communication that have several functions in it. Then Putri [9] conducted a study on the Ethnography of the Tolak Bala Tradition Menyiee Malay tribes and explain the tradition of Tolak Bala through the unit of analysis. The communicative Situation found in the Menyiee tradition in Pangkalan Bunut Village is the situation before and during the tradition tolak bala. Then, the communicative events of the tradition follow Malay farmers in Pangkalan Bunut Village can be seen through types of events, topic, function and purpose, settings, participants, message form, message content, sequence of actions, the rules of interaction, the norms of interpretation. Those several researchs above has a correlation with this research; which is the research that discusses communication patterns through the ethnographic of communication point of view. But the difference lies on the field of study in the form of ritual communication in Cirebon sintren as a form of culture coastal communities.

\section{Research Method}

This research is a descriptive qualitative research. The source of research data is secondary data derived from observations of the ritual procession Sintren Cirebon through YouTube video (https://youtu.be/swiU5bkWgek) [12]. The researcher used non-participatory observation method because researcher did not participate directly in ritual procession due to the pandemic of Covid-19. So, researcher used note-taking technique.

Sudaryanto stated that a research method is a way to gather or analyze the data, meanwhile the technique is the way to implement the method [12]. The method researcher used in gathering the data through observation and interview. The observation method researcher did by observing the procession of the Cirebon Sintren ritual while researcher used the interview method to obtain further details information of Cirebon Sintren ritual through dukun/pawang sintren (sintren handler). And then to analyze the data, this research used domain analysis techniques based on the unit of analysis theory put forward by Dell Hymes in Saville-Troike [11]. The unit of analysis concern settings, events, and act to describe and analyze the activities and patterns of communication in ethnography of communication.

\section{Result and Discussion}

In this research the Cirebon sintren ritual is focused on communication patterns and hidden meanings in traditional songs during sintren ritual. The data were analized using the concept of Dell Hymes in Saville-Troike [11] about the etnography of SPEAKING, especially about the setting (communication situation), event (communication event), and act (communication act).

\section{Communication Situation}

Sintren rituals are held at the arts and culture stage to commemorate the anniversary 535 Cirebon city. Sintren was organized by the Ginanjar Rahayu studio and was located at Ciledug Lor, Ciledug, Cirebon. Participants involved in sintren ritual are a sintren handler (pawang sintren), a girl (sintren dancer), six sintren accompanists, two sinden, gamelan player and accompanist traditional music. Those involved in rituals wear traditional attributes and clothing. This can be seen from one of the examples of the Sintren handler (pawang sintren) wearing traditional clothes in the form of beskap and its full attributes. Things are different seen at what the sintren dancer uses. Before the summoning ceremony began, the girl dressed like a girl in general, but when sintren came down and the cage was opened, the 
girl was wearing a complete traditional dancer dress with jasmine flowers and sunglasses covering her eyes.

\section{Communication Event}

The series of acts of communication in the Cirebon sintren ritual begins when the shaman or Sintren handlers enters the place carrying incense while smelling smoke incense and recites mantras and prayers in all directions. Then six accompaniments of sintren enter the place then the sintren handler makes a prayer then the accompaniment of the sintren encircle sintren handler. Furthermore, the handler and accompanist sintren guide a girl entering the place. The girl was tied all over her body while the traditional song terap banda is sung. In a bound and unconscious state, girl is covered with mats and placed in a large cage. Then, the sintren handler spells the incantation around the cage. Sinden sang traditional song turun sintren while a large cage opened. Then the girl turn into sintren dancer in a bound state and she wears sunglasses (black glasses) and start to dance. Furthermore, sintren dancer is put back in cage while sinden sung traditional song jala tangi. The cage was opened and a girl appeared at her ordinary appearance without being bound. There are three main communication events in this ritual based on the details procession above, namely the communication event when the girl is bound, the communication event during the sintren dancer appears, and communication events when the girl returns to her ordinary look. Therefore, I will focus my analysis on these three sub-communication events.

\section{Communication Act}

There are acts of verbal communication and nonverbal communication in the ritual of Cirebon Sintren and this research focus on the analysis of verbal communication in traditional song during sintren ritual because of those traditional songs are sung in three main communication events of the Sintren ritual, namely the traditional song terap banda when the girl is bound, the traditional song turun sintren as long as the sintren dancer appears, and the traditional song jala tangi when the girl returns to her ordinary appearance.

\section{Acts of verbal communication in traditional song terap banda}

Terap banda song is sung in the act of communication event when the girl who dressed like a normal girl was bound by a sintren handler and the other two peoples. This song is sung repeatedly 11 times during the procession the binding of the girl. There is a symbolic meaning in the gesture of the procession the binding of the girl and then put into an iron cage, which contains the philosophy of a helpless state when people entangled and trapped by invaders. In addition, a sintren dancer must be a virgin girl and have to fast for three days before her performance so that her body remains in a sacred state; the symbolic meaning is that the realm inhabited by spiritst is a very sacred place and people must be physically and mentally sacred and pure when dealing or communicate with the world or the realm inhabited by spirits. 


Song's lyrics
Ana sintren terap
banda
Teng riki
Ana sintren
Dunung jala dunung
Dunung jala dunung
Si Dunung ing bahu
kiwa
Pangeran lara lara
nangis

\author{
Meaning \\ There is a bound \\ sintren \\ Here \\ There is sintren \\ In any place \\ In any place \\ Located in the \\ left hand \\ The prince was \\ hurt hurt in tears
}

Terap banda song is sung at the sintren procession when the girl is tied and then put into an iron cage. In the first fragment: ana sintren banda teng riki, which means there is a bound sintren here, it shows that sinden constructs communication aimed at the spirit of sintren, as well as building a prologue to a story about sintren rituals. Fragment of lyrics dunung jala dunung, dunung jala dunung which means 'in any place, in any place', can be found that this song is an accompaniment to the spirit of sintren in place and in any direction to come and enter the girl's body. Sinden communicates to guide the spirit of sintren to enter the girl's body. Then the lyrics Si Dunung ing bahu kiwa Pangeran lara lara nangis, mean 'placed in the prince's left hand hurt crying'. The choice of lexicon bahu kiwa 'the left hand' and pengeran 'the prince' contain implicit meaning. The implicit meaning of the left hand is the extreme left group, while the meaning the prince is implicitly the leader or public figure. Thus sinden tells about the journey of the Sintren during colonialism. Piece of lyrics it matches the philosophy of the state of society when confined in a snare Dutch colonialism. Si Dunung ing bahu kiwa means 'located in the left hand' (Dutch accusing people of rebel / extreme left groups). Then Pangeran lara lara nangis which means the leader or community leader is hurt and cries with the situation.

\section{Acts of verbal communication in traditional song turun sintren}

In turun sintren song there are differences in the number of repetitions of the lyrics sung. This song is sung when a procession of sintren dancers appears and dances. After being opened from the iron cage the dancer appears in traditional dress like a princess and wears black glases. Symbolic meaning of using sunglasses by sintren dancers are being darkened from the view of his life and the view of his independence by the invaders. Besides, when dancing, sintren tossed coins fainted (unconscious) symbolizes that Indonesian princess cannot be carelessly bought and obtained with money. They are not proud and happy to get money but they are not self-conscious. 


\section{Song's lyrics \\ Turun turun sintren \\ Sintrene widadari}

Eta nemu kembang ning yun-ayunan

Eta nemu kembang ning yun-ayunan

Kembange si Mahendra widadari temurunan

Kembang jahe laos

Lempuyang kembange kuning

Eta lempuyang kembange kuning

Eta lempuyang kembange kuning

Ari balik gage elos

mbesukiki mene maning

Kembang kates kates gandul

Kembu cilik wadah bangkong

Dienteni endah kumpul

Asal banyak uang dikantong

\section{Meaning}

Come come the princess

The princess of the angel

It gets flowers where you want to be taken

It gets flowers where you want to be taken

The flower of Mahendra angel is coming

Galangal ginger flowers

Zingiber's flowers is yellow

That zingiber's flowers is yellow

That zingiber's flowers is yellow

If you go home quickly let it

Come here again tomorrow

Papaya flower is barren

Small pot toad

Waiting for gathering

However a lot of money in the bag

This song is sung when a procession of sintren dancers appears and dances. Turun turun sintren Sintrene widadari Eta nemu kembang ning yun-ayunan Eta nemu kembang ning yunayunan Kembange si Mahendra widadari temurunan fragment of the song repeated 6 times and another piece of song Kembang jahe laos Lempuyang kembange kuning Eta lempuyang kembange kuning Ari balik gage elos mbesukiki mene maning sung three times. Meanwhile, a fragment of the song Kembang kates kates gandhul Kembu cilik wadah bangkong Dienteni endah kumpul Asal banyak uang dikantong, this lyric fragment is rhyming because it rhymes and consists of 4 rows (rows 1 and 2 as sampiran, rows 3 and 4 as contents). This lyric fragment is sung once during sintren tossed coins.

The first fragment of the lyrics turun sintrene sintrene widadari, which means 'Come came the princess The princess of the angel', showing sinden to build the story that the spirit of sintren has entered the girl's body. The next fragment of the Eta nemu kembang ning yunayunan Kembange si Mahendra widadari temurunan Kembang jahe laos Lempuyang kembange kuning, which means 'gets flowers where you want to be taken The flower of Mahendra angel is coming Galangal ginger flowers, Zingiber's flowers is yellow, That zingiber's flowers is yellow'. Sinden construct communication as a form of respect aimed at the spirit of sintren. Meanwhile, a fragment of the song Kembang kates kates gandhul Kembu cilik wadah bangkong Dienteni endah kumpul Asal banyak uang dikantong, sung sinden to create communication aimed at the public (audience), sinden forming and convey communication to the audience to throw coins. So, the metal money was thrown by the public watching this sintren ritual. There are some words in Indonesian; Asal banyak uang dikantong with the aim that the surrounding community who watch Sintren understand that throwing money is one part of the sintren ritual.

Turun sintren song contains many flower terms, flowers that are identical to the fragrant and pleasing aroma is used as a tribute when the spirit angel (sintren) is dancing. There are also words ginger (jahe), galangal (laos), and zingiber (lempuyang) which are described as a typical ancestral concoction to maintain and support the appearance of a princess. Other forms of respect for the spirit of sintren are also present in the word "Kembange the Mahendra", Mahendra or Dewi Mahendra is one famous puppet figure, she is the daughter of Prabu Kurandapati, a king of the land Widarba.

The choise of the floral lexicon are in ginger (jahe), galangal (laos), and zingiber (lempuyang) in Turun sintren song. These three plants are included in the types of herbal 
plants which are herbal ingredients beneficial for health and beauty. Ginger is a sticky rhizome plant used as a spice and medicinal ingredient. While galangal (laos) is known community as a mixture of cooking spices and medicinal ingredients. While the zingiber (lempuyang) is a type of spice used as one of the main ingredients of herbal medicine or traditional medicinal drinks. These plants can grow in low-lying areas to high. The choise of the ginger (jahe), galangal (laos), and zingiber (lempuyang) lexicon in the song Turun sintren as a reflection of the characteristics of the people of Cirebon who live in areas with geographical conditions of lowlands and highlands. In addition, the choice of the words ginger, laos, and lempuyang, are everyday plants that they encounter. This is caused by man's closest relationship is with nature, because the true use of language in a society cannot be separated from its natural environment. This shows that language and environment are two aspects that are sustainable and mutually exclusive influence.

\section{Acts of verbal communication in traditional song jala tangi}

This song accompanied the final procession of the sintren ritual when the girl was released from the bond and she returned to her usual state. Song of Jala Tangi is sung three times by Sinden. The symbolic meaning of the release of ties to the whole body of the girl symbolizes the people rose from the trappings of colonialism and became free from all forms of colonialism.

\author{
Song's lyrics \\ jala tangi layung langit \\ langit sewu bedil mati \\ langit sewu badan lara \\ hayu eceu urang balik \\ mun balik ka umah sira \\ jala gandrung eling
}

\author{
Meaning \\ Rise up wherever the sky is reddish \\ One thousand sky weapons dead \\ A thousand heavens body aches \\ Come on you go home \\ Return to your house \\ Wherever quickly come to your sense
}

In the fragments of the lyrics jala tangi layung langit hayu eceu urung balik mun balik $k a$ umah that means 'rise up wherever the sky is reddish come on you go home return to your house', we can find that this song is an accompaniment to the spirit of sintren in any place and direction leaving the girl's body. Sinden forming communication intended to guide the spirit of sintren back to the place of origin she lives in. Then in the lyrics jala gandrung eling, meaning 'wherever quickly come to your senses', Sinden establishes communication with the girl so that she regains consciousness and recovers after the spirit of Sintren has left her body. Selection of lexicon bedil mati (dead weapon) and badan lara (sick body) contains implicit meaning. The implicit meaning of bedil mati is when the invaders take up arms and leave their colony, meanwhile the implicit badan lara is a form of people's struggling to escape from the trap of colonialism. Thus sinden narrates the conditions of the people's struggling to rise from the bondage of colonialists and independence from all forms of colonialism. Thus, traditional songs during sintren ritual not only as a form of respect for the spirit of sintren but also as a sinden's narrative to tell the conditions of people's struggle to rise from the bondage of colonialists and become independence from all forms of colonialism.

The language used in traditional songs during sintren ritual is a frozen language where the songs are special songs for accompaniment sintren ritual. In addition, the three songs contain 2 regional languages namely Javanese and Sundanese languages. It is as a 
manifestation of the Cirebon society as a whole that Cirebon society comes from the acculturation of Javanese-Sundanese language and culture. Traditional song during sintren and ritual procession in it indicate transformation of the function sintren ritual time after. This happens due to several aspects, such as religion aspect, politics aspect and economic aspect. At the beginning of its appearance, sintren is a magical and sacred ritual which is used as a medium of prayer and asks for blessings in tradition sea alms or Nadran (forbid offerings to the sea). However, along with the entry religion of Islam brought by Sunan Gunung Jati in Cirebon, Sintren ritual confronted acculturation with Islamic culture and sintren become a media contribute to the spread of Islam, so that prayer upon God and prayer upon prophet are slipped in it. During the colonial period, sintren ritual was used as a political tool as a narrative of the people's struggle and resistance to the colonial authorities. Over time, this ritual is found on family occasions, such as sunatan and weddings, besides that, the ritual of sintren is also often held on the stage of art as a medium to preserve local traditions and wisdom.

\section{Conclusion}

Through traditional song in sintren ritual sinden builds communication with three participants; spirit of sintren, the girl, and the public (audience). The choice of the variant lexicon in the song is as a reflection of the characteristics of the relationship Cirebon society with its environment, both the natural environment and the social environment. The choice of the floral lexicon in traditional song lyric during sintren ritual reflects the harmonious relationship between human beings and nature. Ginger (jahe), galangal (laos), and zingiber (lempuyang), these three plants are included in the types of herbal plants which are herbal ingredients beneficial for health and beauty. These three lexicons are reflection of the characteristics of Cirebon society who live in areas with geographical conditions of lowlands and highlands. In addition, the choice of the words ginger, galangal, and zingiber are everyday plants that they encounter. This is caused by man's closest relationship is with nature, meaning language use in a society cannot be separated from its natural environment. This shows that language and environment are two aspects that are mutually sustainable and influence one another. Meanwhile the symbolic meaning in the fragment of the song and the gesture of the sintren procession reflect the state of society during the colonial period. Traditional Songs of sintren is sung not only as a form of respect for sintren spirit but also as a sinden narrative to tell the conditions of the people's struggle to rise from the trap of colonialism and independence from all forms of colonialism. 


\section{References}

1. Aditama, Luthfi Deska, Kesenian Sintren sebagai Karifan Lokal Ditinjau dari Metafisika Anton Bakker. J.P.H 21.1, 57-72 (2016)

2. Ahmadi, Dadi, Interaksi Simbolik Suatu Pengantar. J.M 9.2, 301-316 (2008)

3. Hamad, Ibnu, Komunikasi sebagai Wacana. J.M 7.2, 259-268 (2006)

4. Handayani, Sri, Pola Komunikasi Ritual Slametan Musim Tanam Padi di Ngemplak, Sambikerep, Surabaya. J.I.K 5.1, 40-50 (2018)

5. Kuswarno, Engkus, Tradisi Fenomenologi pada Penelitian Komunikasi Kualitatif. J.M 9.1, 161-176 (2006)

6. Littlejohn, Stephen W, Teori Komunikasi (2009)

7. Manafe, Yermia Djefri, Komunikasi Ritual pada Budaya Bertani Atoni Pah Meto di Timor-Nusa Tenggara Timur. J.K 1.3, 287-298 (2011)

8. Miryanti, Desi, Etnografi Komunikasi dalam Tradisi Thugun Mandi. Jom.FSIP 4.2, 115(2017)

9. Putri, Septyani Adiyan, Etnografi Komunikasi Tradisi Tolak Bala Menyiee Suku Melayu Petalangan. Jom.FSIP 4.1, 1-11 (2012)

10. Rifa'i, M, Etnografi Komunikasi Ritual Tingkeban Neloni dan Mitoni. J.E 2.1, 28-39 (2017)

11. Saville-Troike, Muriel, The Ethnography of Communication: an Introduction (2003)

12. Sudaryanto. Metode dan Teknik Analisis Bahasa (2015)

YouTube, Beskem Video, Takjub Atraksi Sintren Cantik. YouTube:

https://youtu.be/swiU5bkWgek (2017) 